\title{
IMPLEMENTATION OF MARKETING MIX STRATEGY FOR START-UP BUSINESS: FRUIT COMBINING
}

\author{
Yuliantoro R. ${ }^{*}$, Syah T.Y.R., Pusaka S., Darmansyah H.S. \\ Faculty of Economics and Business, Esa Unggul University, Jakarta, Indonesia \\ *E-mail: riboetgki29@gmail.com
}

\begin{abstract}
Nowadays, business rivalry in the food and beverages industry is going tightly and pushes the company to planning innovative marketing strategy. To capture the market needs, the company should have added value to their product. In addition, the company must also have a good marketing strategy to attract potential consumers. Fruit combining is one of creative innovation product that combines the original fruit and jelly in one package, which combines the need for vitamins in fruits and fibbers in the jelly. Fruit combining are expected to be the solution in modern society to save the fruit. Not even in the flavor of fruit, but it can also represent an alternative for daily fruit consumption society. Urban family activities are indeed heavy, if they not had time to cut and processing fresh fruit at home, fruit combining products could be a good alternative to substitute the need for fibber and vitamins needed by the body. In order to compete and hold out, focusing activity and company business process have to concentrate in dynamic customers needs until purpose of filled customers needs and customers satisfaction will completed, because of that, our start up business focusing on how to selling of their new product fruit combining. The purpose to be achieved are to give more innovative marketing strategy based on society dynamic changes to arrogate the fruit combining market. Analyze and information obtained and limited in Banten and Jakarta area. Result and conclusion from these researches are about information of consumer behaviors concerning to fruit combining products and information about strengthen and weakness of the product see based on current marketing concepts. And the end, based on received and refined data, we conclude that a strategic marketing planning will arrogate market, brand awareness and market educated from fruit combining special quality.
\end{abstract}

\section{KEY WORDS}

Marketing, strategy, planning, marketing mix.

Nowadays, the competition in the food and beverages industry is getting tight. It can be seen from the number of products in circulation quite a lot, so consumers should be selective. To capture the desired market, the company should have added value to the product being sold. In addition, the company must also have a good marketing strategy to attract potential consumers.

Fruit combining is one of creative innovation product that combines the original fruit and jelly in one package, which combines the need for vitamins in fruits and fibers in the jelly. Fruit combining are expected to be the solution in modern society to savor the fruit. Not even in the flavor of fruit, but it can also represent an alternative for daily fruit consumption society.

Urban family activities are indeed heavy, if they not had time to cut and processing fresh fruit at home, fruit combining products could be a good alternative to substitute the need for fiber and vitamins needed by the body.

Having this opportunity, PT Redceri Indonesia tried to launch a fruit combining products: Redceri Pure Fruit Jelly with two variants i.e. Orange and Carica. This product is trying to enter in a niche market which is currently in the domination by import products such as Tarami from Japan, Korea and of Tutto Sun Moon from Singapore. Although there are other similar products that have been circulated, PT Redceri Indonesia gives added value of this new product. Competition entered quite large, the company tried to do a marketing strategy planning to sell this product so that it can be accepted by the community or consumer. 


\section{METHODS OF RESEARCH}

A description of the marketing strategy planning and marketing mix PT Redceri Indonesia refers to the organizational planning framework as follows:

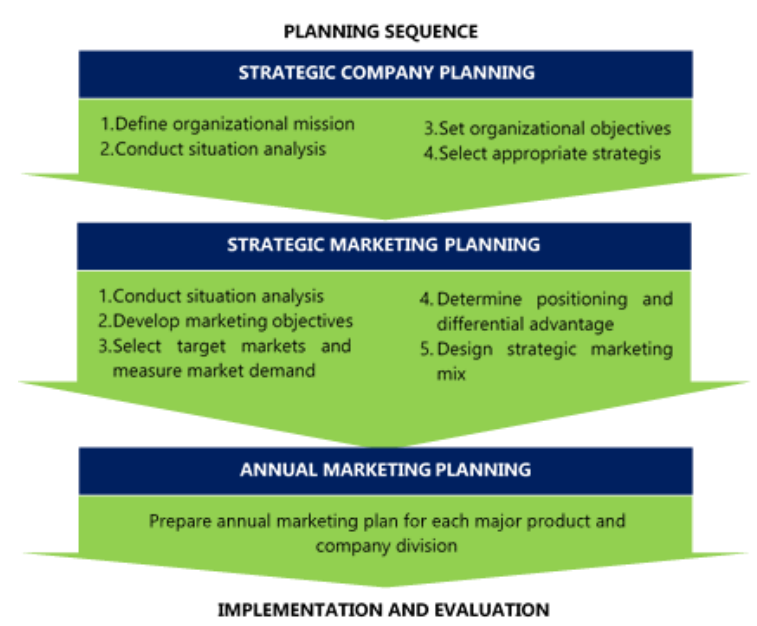

Figure 1 - Three Levels of Organizational Planning (William J. Stanton, Fundamentals of Marketing, 10th Edition)

In the company marketing plan includes 5 (five) stages of the process, i.e. as follows: conduct a situation analysis; develop marketing objectives; choosing a target market and measuring market needs; determining the position (Positioning); designing a marketing mix strategy.

\section{RESULTS AND DISCUSSION}

Situation analysis is conducted by the company to understand the marketing environment towards the products offered. The marketing environment consists of fruit combining business people and outside marketing forces that can influence marketing management's ability to develop and sustain successful transactions with its targeted customers.

Intensity of rivalry, not only PT Redceri Indonesia which produces food or beverage types of fruit combining in packaging to customers in Indonesia. Based on the analysis of strategic groups, there are currently 3 (three) fruit combining manufacturers who selling their products in Indonesia such as Tarami Corporation Japan, Tutto Company Ltd. Korea, and Sun Moon Food Company Ltd. Singapore refers to the analysis that makes them a major threat to PT Redceri Indonesia's market segment. Some of the strategies that the company performed to win the competition and survive is to determine how to improve the quality of products that produced, taste, and service to consumers well by trying new ways and new product innovations that increasingly more to attract customers. In addition, the company pricing strategy by pressing product prices through the utilization of distribution cost increment issued by the competitors so as to attract as many consumers in the market without lowering the quality of the product.

Currently, many local producers who only focus on producing jelly potentially become a competitor for PT Redceri Indonesia. However, this does not necessarily make jelly producers easily enter the fruit combining industry because it will get a lot of difficulty in entering the market, especially the problem of processing technology.

The availability of many substitute products will limit the flexibility of players in the industry to determine the selling price of the product. The substitute product will be one of the threats to the products offered by the company such as fruit yoghurt, fruit juice, and candied fruit. 
Market growth, the growth of per capita fruit consumption value in Indonesia each year has increased by $14.85 \%$. In 2016 , the projected value of money circulating in the community for fruit consumption reaches more than 74 trillion Rupiah.

Table 1 - Projected Expenditure Increasing per Capita Consumption of Fruit, 2015-2020

\begin{tabular}{cccc}
\hline Year & $\begin{array}{c}\text { Total } \\
\text { Expenditures } \\
\text { Per Year (Rp) }\end{array}$ & $\begin{array}{c}\text { Consum } \\
\text { ption } \\
\text { Rate } \\
(\%)\end{array}$ & $\begin{array}{c}\text { Fruit } \\
\text { consumpti } \\
\text { on per } \\
\text { capita } \\
\text { (Rp.) }\end{array}$ \\
\hline 2010 & 1.416 .358 .027 .032 .000 & $2,46 \%$ & 34.842 .407 .464 .987 \\
2011 & 1.723 .934 .003 .097 .600 & $2,46 \%$ & 42.408 .776 .476 .201 \\
2012 & 1.865 .042 .051 .745 .600 & $2,46 \%$ & 45.880 .034 .472 .942 \\
2013 & 2.100 .704 .535 .049 .200 & $2,46 \%$ & 51.677 .331 .562 .210 \\
2014 & 2.348 .255 .448 .883 .200 & $2,46 \%$ & 57.767 .084 .042 .527 \\
2015 & 2.664 .432 .341 .415 .940 & $2,46 \%$ & 65.545 .035 .598 .832 \\
2016 & $\mathbf{3 . 0 2 2 . 0 5 0 . 6 8 3 . 7 3 1 . 9 7 0}$ & $\mathbf{2 , 4 6 \%}$ & $\mathbf{7 4 . 3 4 2 . 4 4 6 . 8 1 9 . 8 0 6}$ \\
2017 & 3.426 .378 .625 .141 .230 & $2,46 \%$ & 84.288 .914 .178 .474 \\
2018 & 3.883 .326 .569 .827 .500 & $2,46 \%$ & 95.529 .833 .617 .757 \\
2019 & 4.399 .533 .773 .714 .140 & $2,46 \%$ & 108.228 .530 .833 .368 \\
2020 & 4.982 .470 .086 .779 .580 & $2,46 \%$ & 122.568 .764 .134 .778 \\
\hline
\end{tabular}

Processed from the results of the National Socioeconomic Survey (Susenas); Quarter I-2012, I-2014, BPS.

This is a great potential in the utilization of fruits offered to the community in different forms. With such growth value and with the abundant supply of fruit and not yet utilized, is an opportunity for companies to run this business.

The fruit combining industry has an important role for the national food industry, especially in fulfilling of the fruit demand, especially the need for vitamins. The percentage of fruit as a source of vitamin is $4.26 \%$ of all common food ingredients consumed.

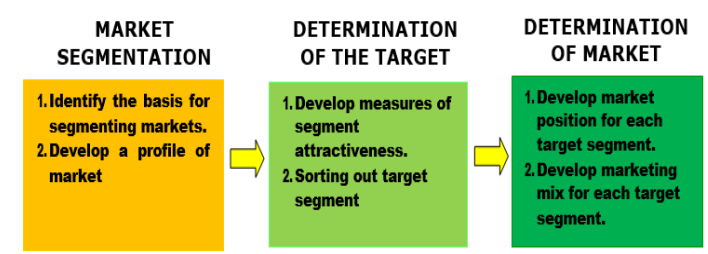

Figure 2 - Market Segmentation Steps (Source: William J. Stanton, Fundamentals of Marketing, 10th Edition)

The level of consumption of fruit is very large, this is a potential market for PT Redceri Indonesia. The availability of fruit combining is still limited, because the existing producers are still limited from abroad or imported products. In addition, the public difficulty in finding fruit combining that can provide assurance from the quality, halal and affordable prices. Fruit combining that existing today is still quite expensive and has a taste that is less suitable for the people of Indonesia.

Market access, the company as effectively as possible managing access strategy enters the market for the success of the company's overall business model. Applying the right market access strategy is supported by the specific tools needed to manage the sales network in the company's distribution system. In addition, the success rate of entry into the market really depends on the competitive advantage of the fruit combining products offered by the company.

In the early stages of production, PT Redceri Indonesia entered the market through two ways of marketing, namely indirect sales and direct sales. Indirect sales, the company sell the products through food and beverage distributors, while the direct sales through cooperation with Indomaret retailers or hospitals.

Determination of the marketing objectives to be achieved by the company must be in harmony with the vision, mission and strategy that the company sets and must be able to translate the strategy and goals of the company's organization. The first objective is within 
the next five years to become a market leader in the food and beverage industry that creates natural products in the marketing areas of Jakarta and Banten, has a strong distribution channel and builds strong brand awareness, and reaches $15.52 \%$ Return of Investment in the first year $(\mathrm{Y}-1)$ of the total sales revenue and change the salary payment system of all sales marketing employees from salary compensation base to sales commission base, it aims to motivate the increase of selling rate of products offered.

Market segmentation and market diversity are two interrelated concepts. Without a diverse market of people with different backgrounds, countries of origin, interests, needs, and desires, there is little reason to market segmentation.

Before the acceptance of the broad marketing concept the common way to do business with consumers is through mass marketing, which is the same product offering or marketing mix to everyone. Market segmentation follows as a more logical way to meet consumer needs.

Market segment, buyers have unique needs and desires, potentially, each buyer is a separate market. To that end, the company determines the market segment based on income groups and age groups.

In the group of earnings the company takes the market segment for groups of people with middle income upwards. As for the age group the company sets the market segment for the age group of 5 (five) to 49 (forty-nine) years. The variable determination of market segments of the company can be classified as follows:

Table 2 - Variable Determination of Market Segments

\begin{tabular}{lll}
\hline VARIABEL & & KETERANGAN \\
\hline Geografis & Wilayah & Jakarta dan Banten \\
& Luas Wilayah & $7.659 \mathrm{Km}^{2}$ dan $9160 \mathrm{Km}^{2}$ \\
& Populasi & 9.988 .329 dan 10.469 .523 jiwa \\
& Pemerintah & Propinsi \\
& Iklim & Kemarau dan Penghujan \\
Demografis & Umur & $5-49$ tahun \\
& Jenis Kelamin & Pria - Wanita \\
& Ukuran Keluarga & $1-2,3-4,5+$ \\
Psikografis & Pendidikan & Sekolah Dasar - Perguruan Tinggi \\
& Kelas Sosial & Menengah ke atas \\
& Gaya Hidup & Achievers \\
& Kepribadian & Suka berteman \\
& Kesempatan Belanja & Kesempatan tetap \\
& Manfaat Yang Dicari & Kualitas dan Ekonomis \\
& Tingkat Kesiapan & Menyadari \\
& Sikap Terhadap Produk & Antusias dan Positif \\
\hline & \multicolumn{3}{l}{}
\end{tabular}

Geographical segmentation, in the early stages of marketing the company set the market share in the Jakarta and Banten areas. With the population growth rate in the region reaching $2.1 \%$ per year. In addition, the company determines the effect of climate on its marketing mechanism. Based on market behavior, for food and beverage products with the content of fruit or juice will increase demand during the dry season and tend to decline during the rainy season.

Demographic segmentation, on this assignment the company offers its products for the 5-49 years age segment, because the products offered are designed to suit the particular needs of a particular age segment. Redceri Pure Fruit Jelly products use native fruit instead of fruit juice so it is not suitable for less than 5 years old that have not been able to chew. In addition, this product also uses pure sugar that is not suitable for the market segmented age over 49 years related health issues about excess sugar consumption that causes diabetes. In addition, the company does not include or specific designation of segmentation based on gender, educational level and family size. This is because Redceri Pure Fruit Jelly products offer general products with the benefit of consuming fruit and fiber consumption.

Psychographic segmentation, people's purchasing power dependence still has a strong influence in preference to the desire to buy a product. To that end, the company sets its market segment for upper middle-class social class by building traits that can attract the interest of the class society such as strengthening brand awareness in the form of packaging 
or display and the quality of class products. When compared with the original fruit, the culture of the people in consuming fruit combining fruit is still not popular. However, with the modern lifestyle changes that want practicality, there is a special market segment that is large enough to work on. This is evident from the number of fruit consumption from year to year increased and reached the number of tens of tons. Specific market segment in question is the market segment that does have a passion and taste to consume fruit with more practical and easy to get (Customer Familiarity). In addition, the attraction of people to the goods is influenced by lifestyle and the goods are able to express the lifestyle. Companies are trying to improve market segmentation based on consumer lifestyles as well as certain community groups. Redceri Pure Fruit Jelly is positioned as the ideal food product for healthy, natural, halal and active or mobile lifestyle. Finally, PT Redceri Indonesia is targeting achievers as a marketing appeal of its products.

Segmentation of behavior, consumers can be grouped according to knowledge, attitude, use, and response to a product. Of the trusted behavior variables are the best starting point for building specific market segments. Indonesian people have a habit of consuming fruit only at lunch, for that company needs to build a brand image that the product offered can be consumed throughout the day. In addition, the company uses the benefit segmentation to position the Redceri Pure Fruit Jelly product as halal, healthy and economical. This is useful for building consumer awareness of healthy living as well as enthusiasm and positive responses to the products that the company has to offer.

Target market, based on market segmentation that has been done, company set main target market is age group of 10-29 years with middle social class and above. This is set to simplify the marketing communication pattern of Redceri Fruit Jelly products at an early stage. The target setting is described as in the table as follows:

\begin{tabular}{|c|c|c|c|c|c|c|}
\hline \multicolumn{7}{|l|}{ SEGMEN PASAR } \\
\hline \multirow{2}{*}{\begin{tabular}{|l|} 
Sosial Ekonomi \\
Gender \\
\end{tabular}} & & \multicolumn{2}{|c|}{ Menengah } & & \multicolumn{2}{|c|}{ Atas } \\
\hline & & Pria & Wanita & & Pria & Wanita \\
\hline \multicolumn{7}{|l|}{ Kelompok Umur: } \\
\hline $5-9$ & $9.423,80$ & $4.735,46$ & $4.688,34$ & $4.711,90$ & $2.367,73$ & $2.344,17$ \\
\hline $10-14$ & $9.030,84$ & $4.538,00$ & $4.492,84$ & $4.515,42$ & $2.269,00$ & $2.246,42$ \\
\hline $15-19$ & $8.864,40$ & $4.454,36$ & $4.410,04$ & $4.432,20$ & $2.227,18$ & $2.205,02$ \\
\hline $20-24$ & $8.627,60$ & $4.335,37$ & $4.292,23$ & $4.313,80$ & $2.167,68$ & $2.146,12$ \\
\hline $25-29$ & $8.364,56$ & $4.203,19$ & $4.161,37$ & $4.182,28$ & $2.101,60$ & $2.080,68$ \\
\hline $30-34$ & $8.198,80$ & $4.119,90$ & $4.078,90$ & $4.099,40$ & $2.059,95$ & $2.039,45$ \\
\hline $35-39$ & $7.974,60$ & $4.007,24$ & $3.967,36$ & $3.987,30$ & $2.003,62$ & $1.983,68$ \\
\hline $40-44$ & $7.443,72$ & $3.740,47$ & $3.703,25$ & $3.721,86$ & $1.870,23$ & $1.851,63$ \\
\hline $45-49$ & $6.662,80$ & $3.348,06$ & $3.314,74$ & $3.331,40$ & $1.674,03$ & $1.657,37$ \\
\hline
\end{tabular}

Source: Processed from BPS data in 2014.

From the table 3, the age group of $10-29$ years (yellow mark) reached $62.36 \%$ of the total market segment 5-49 years age group with middle and upper social class. Companies in the early stages of using an undifferentiated marketing strategy with one offer to enter the market. Redceri Pure Fruit Jelly's product offerings will focus on the general needs of consumers, not to differentiate. This is done by the company at an early stage to make cost savings such as similar product lines keeping production, inventory and transportation costs low.

However, the company will keep in mind the product life cycle stage, for which the company strengthens the Research and Development Division to conduct market research and product development based on the segmentation that has been done. Currently, competitors in the market still use all-round marketing.

Positioning is an action in shaping the image in the minds of consumers (Kotler, 2006). In the positioning statement there should be a formula established on: Target Segment - an explanation of the segment targeted by the company, Brand Name - the name of the product offered, Frame of Reference - the product category offered, Point of Differentiation - the 
uniqueness of the offered product compared to Products of the same category, and Reason to Believe - evidence to reinforce the uniqueness of the product offered (Tybout \& Calkins, 2005).

Based on it, the company tries to shape the product image with product Tagline for Redceri Pure Fruit Jelly's is 'Your Pure Fruit Jellycious', while its Positioning Statement is 'Untuk masyarakat Indonesia yang sehat, Redceri Pure Fruit Jelly adalah fruit combining kombinasi jelly dengan buah-buahan segar sebagai asupan vitamin yang halal, praktis dan rasa yang berbeda karena hanya Redceri Pure Fruit Jelly produk dalam negeri yang di proses secara higienis dan modern'.

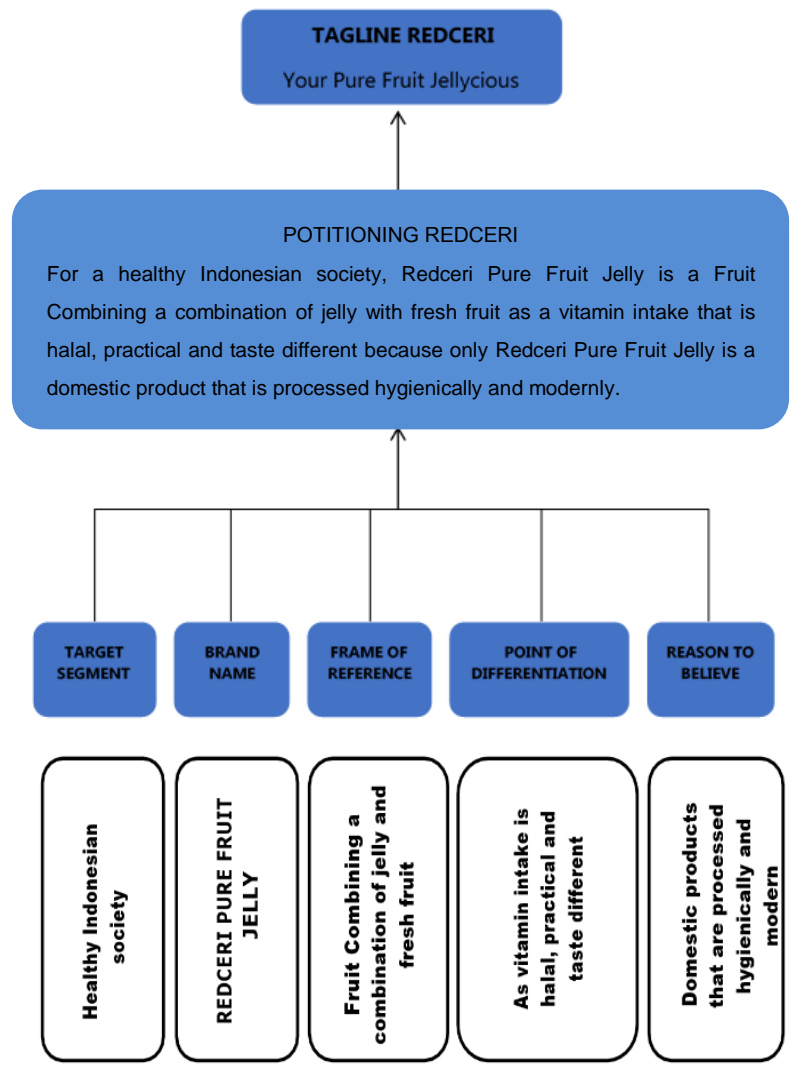

Figure 3 - Positioning Statement

Marketing mix is a marketing strategy used by a company to market Redceri Pure Fruit Jelly products. As for the marketing of its products, the company establishes two marketing mechanisms namely direct sales through cooperation with retailers or hospitals with the concept of business to customer (B2C) and sales through cooperation with distributors with the concept of business to business (B2B). To be able to enter into the sales of fruit combining to such parties, the company notices several things such as: product - hygienic and gives clear benefits and prices - as a substitute product no more expensive price of substituted goods.

Marketing strategy for direct sales through cooperation with retailers or hospitals or B2C concept using 4P (Product, Place, Price, Promotion). The translation of these strategies is:

Product, according to Kotler: in planning product offerings to customers should have five levels that each level gives more value to customers. Five levels are Product Core Benefit, Basic Product, Expected Product, Augmented Product and Potential Product.

For Redceri Pure Fruit Jelly are as follows: Product Core Benefit: Fruit Combining fruits and jelly; Basic Product: natural, halal and practical in enjoying the fruit; Expected Product: the freshness of the fruit is maintained and the taste fits with the tastes of the people of 
Indonesia; Augmented Product: attractive, clean and hygienic packaging; Potential Product: Orange and Carica flavors.

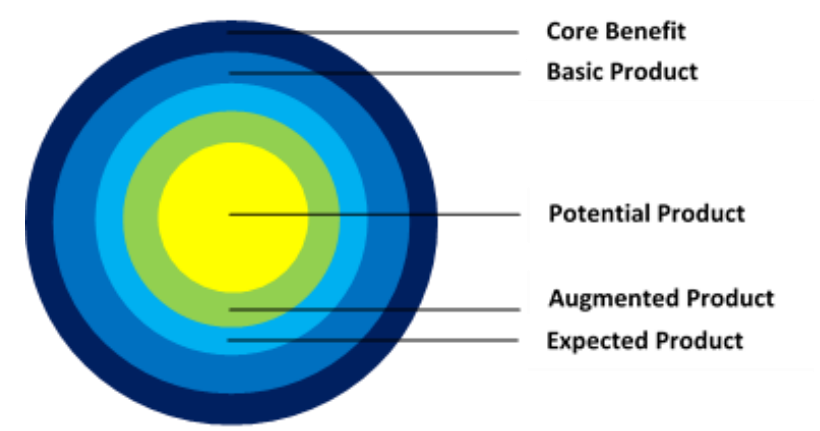

Figure 4 - Five Levels of Product (Source: Kotler 2003:408)

Product specification form, Redceri Pure Fruit Jelly is packed in a natural PP (polypropylene) cup. Product weight per cup is 110 grams, and each product comes with a spoon of jelly. Redceri Pure Fruit Jelly is marketed there are two types of flavor: Orange and Carica.

Product packaging, Redceri products will be packed in a natural PP (polypropylene) cup and covered with lid cup PE (polyetylene) in printing the logo and product type. The Redceri product is packed in a corrugated carton with the contents of each carton 24 cups.

Product advantages, Redceri products compared with fruit combining others is more fruit content, halal, and taste that suits the tastes of the majority of Indonesian people.

Logo design, so that the product is easy to remember and give a positive impression so that the company can communicate the right promotional strategy target, to create high brand awareness. The Redceri product logo design is as follows:

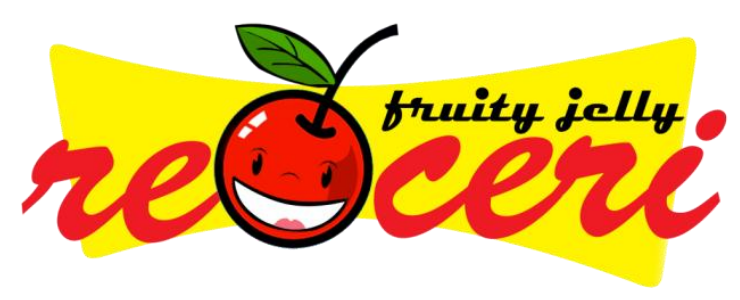

Figure 5 - Logo Design

Place, for B2C's Redceri product marketing, the company will distribute itself from direct production to parties such as a retailer or a particular hospital using its distribution fleet. Based on the purchase order of the parties, the company will process the existing request and make direct delivery using the prepared distribution fleet.

Price, in setting product prices using Cost plus Pricing Method pricing strategy, i.e. pricing based on total cost by adding profit. This is done by the company to penetrate the market that is currently dominated by imported products with a relatively expensive price. This can provide more value through improving the quality of products and services better than competitors, and also later with the brand will add value to the product even if the price set is not higher than the competitors. The price set by the company is Rp 7,450, - / cup including Vat. The price is for the first year and made fixed (not fluctuating), for the second year and subsequently adjusted for inflation plus other factors because the fruit combining Redceri has become known by the public. The company also applies HET (Highest Retail Price) with the aim of the consumer can get a reasonable price. The highest retail price currently applied is $\mathrm{Rp} 7,450$, -/cup and Rp 178,800, -/box.

In addition, the company offers discounts for cash discounts of up to $3 \%$ of total purchases. Being for decision makers at these agencies, in order to create long-term 
relationships the company provides a budget of $5 \%$ of total purchases in the form of entertainment and the provision of fees (incentives).

Promotion, promotional activities are aimed at informing, persuading, or influencing consumers to use the products produced by the company. Promotional activities undertaken by the company is the spread of flyer, radio advertising and digital marketing.

One of the promotional activities undertaken by the company through digital marketing that is by utilizing electronic media for the purpose of promoting, marketing, and others.

Increased internet users today become something that should not be ignored by the business. The advantage of going through digital marketing is the product or service that we sell can be recognized by many people.

Based on the description, the company will implement some promotional strategies through digital marketing as follows:

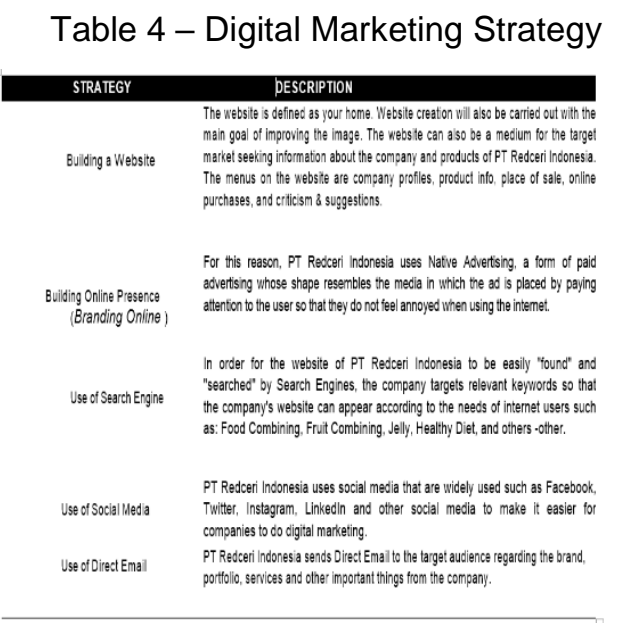

Marketing strategy for indirect sales through cooperation with food and beverage distributors or B2B concepts using NICE approach (Networking, Interaction, Common interest, Experience). The translation of these strategies are:

Networking, by establishing networks between companies and distributors in each region to facilitate the opening of distribution channels in the target market area. To that end, the company to explore the distributors who are in Jakarta and Banten region with mutually beneficial cooperation. The food and beverage distributors such as PT Intrasari Raya in Jakarta and PT Era Gading Baharu in Tangerang become partnership company to build marketing network of Redceri Fruit Jelly products. Distributor distributors become parties that will distribute to third parties up to end customers.

Interaction, the company creates communication and good relationship with the distributor in introducing the products that the company has to offer. This communication is also related to the service to the order and ease of handling the claim of the product defect.

The marketing and sales team of the company will communicate the product of Redceri Fruit Jelly by direct door to door product exposure to every food and beverage distributors that are the target partners in opening the marketing network.

Common Interest, the company tries to establish relationships and mutual relationships with distributors, especially decision makers through personal approaches. One of them is the provision of sales commissions and annual rewards against sales targets given to each distributor.

To build long-term partnership with distributors, the company has prepared a total budget of $8 \%$ of the related sales budgeted from 3\% discount cash sales and $5 \%$ of the costs of entertain. This budget is issued for the achievement of sales targets in the form of commissions, fees and annual rewards.

Experience, strategy in deepening product knowledge of products offered to support product introduction process to distributor. Every sales and marketing personnel from PT 
Redceri Indonesia should be able to understand the products offered both in terms of product benefits, benefits gained, and product handling.

To maintain and keep customer loyalty, PT Redceri Indonesia needs to design a sales blueprint in serving customers. Sales blueprints are sales guides to consumers systematically illustrated, from first time in touch with brands to after sales. Sales blueprints can be developed for brand owners who are just getting started or for improvisation.

Sales blueprint can be a reference or standard operation procedure (SOP). In the sales blueprint, the company measures the sales success of the five dimensions of sales effectiveness: (1) Company Results; (2) Customer Results; (3) Activities; (4) Salespeople; (5) Sales Effectiveness Drivers.

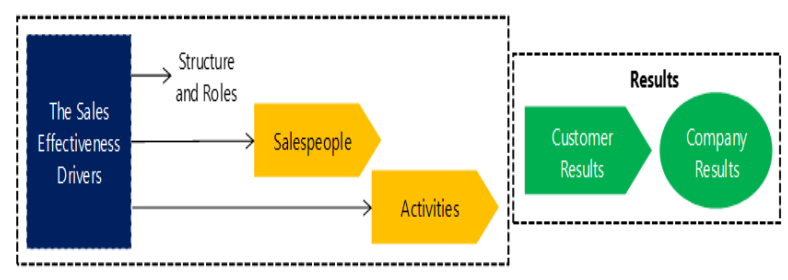

Figure 6 - Relationship between Dimensions Sales Organization (Source: Andris A. Zoltners, Prabhakant Sinha, Sally E. Lorimer, Building A Winning Sales Force, 2009)

Company Results, on this dimension the company focuses on goals or outcomes for the company. The results to be achieved are as follows: Market share in the first year of $5 \%$ of the total fruit demand in the area of Banten and Jakarta, with a sales value of 71, 6 billion; Target profit in the first year of 4.8 billion or $6.69 \%$ of total sales; Return of Investment which become target company is $15,52 \%$ per year; Marketing cost of $31 \%$ of total sales per year.

The sales proceeds will be evaluated and rewarded for the achievement of the goal, and the result is the most visible and objective indicator of success. Company results are the organization's financial results, in which the sales force's efforts play a major role. These results can be measured using sales, profits, market share, return on investment, or some other metric, and can be expressed as absolute levels, percentage of goal achievement, or growth over the past year. This is useful for evaluating outcomes from short and long term perspectives, as decisions involving salespeople affect both.

Customer Results, in this dimension the company focus on the results or benefits to be gained by consumers. Sales force activity at this stage is to build good relationships and customer trust, as well as build a loyalty bases on the products offered. The steps taken are:

- Establish communication and good relationships with distributors when introduce the products that the company has to offer;

- Providing services to orders and ease of handling claims for problematic products;

- Direct door to door product exposure to each distributor of food and beverage that is the target partner in opening the marketing network;

- Promotion of products, to inform, persuades, or influence consumers to use products produced by the company;

- Personal approach by giving sales commissions and annual rewards to sales targets given to each distributor and giving gifts to end users such as sweepstakes or prizes directly.

The results of the customer affect the company's results; therefore the company measures customer outcomes by using customer satisfaction scores and customer retention rates or repeat sales to assess how customers view sales organizations. Customers will not buy from people they do not like.

Activities, in this dimension, the company emphasizes salespeople to effectively allocate their time and ensure that every activity is of high quality and value. The steps taken by PT Redceri Indonesia's sales force are as follows:

- Salespeople serve our best customers well; 
- Salespeople spend a lot of time with customers and keep the administrative work to a minimum;

- Quality of sales force activity is as important as quantity.

Salespeople' activities are usually organized into a multistep process that includes steps such as lead generation, needs analysis, solution development, proposal presentation, negotiation, installation, customer service, and maintenance and marketing expansion. Sales force activity encourages customer results.

Salespeople, in this dimension PT Redceri Indonesia's sales force are formed to have the ability and mindset as follows:

- Salespeople are the spearhead of the company;

- Salespeople must have knowledge of products, customers, and competitors very well;

- Have the right values, attitudes, and abilities;

- Want to learn and develop new skills;

- Be able to adapt when new sales process arises;

- High performance turnover is very low.

Companies seek to employ competent and motivated salespeople and build a 'success' culture to direct them to demonstrate effective behavior and engage in effective activities. Sales force PT Redceri Indonesia is a strong revenue driver for the company, so salespeople is the most important asset of the company because of its relationship with the customer that determines the company's success.

Sales Effectiveness Drivers, in this dimension the company focuses on decisions, processes, systems, and work programs of salespeople. The drivers of PT Redceri Indonesia's sales force are:

- Definer Drivers:

These drivers determine the organizational structure of sales force, number of sales force and territory design. In the early stages of production of PT Redceri Indonesia the marketing focus in Banten and Jakarta. Based on that territory marketing of PT Redceri Indonesia product is divided into two marketing areas namely Banten and Jakarta. The number of marketing personnel for each region is 1 person sales force and 1 person marketing staff. For the marketing division is headed by a Manager, namely Marketing and Sales Manager. Structurally, the manager is responsible for the performance of marketing personnel. Sales and marketing personnel will provide performance reports, market developments, and matters related to the company's marketing to managers.

- Shaper Drivers:

These drivers form the skills, abilities and values of sales people / key person through: (1) Recruiting, for marketing personnel and sales force at least D-3 education while for minimal manager of $\mathrm{S}-1$ education with technical skills such as computer mastery, communication, Selling skills and good analytical skills. (2) Learning and development, to support the personal abilities of corporate salespeople provide training such as interpersonal skills, effective communication skill, business law and other related training. (3) Culture, embedded culture: 'Quality first, working hard and family number one' from a sales standpoint. (4) Sales Management Team, it aims to create High Impact Sales Management and Strategy. (5) Coaching, training by bringing in marketing or senior sales to become a role model, and sharing the real experience of why he / she can be the best (in terms of sales). (6) Leadership, has the ability to lead, firm in making decisions and responsible for decisions taken.

- Enlightener Drivers:

In these drivers the company seeks to provide and provide useful and supportive information for salespeople such as consumer research, target markets, data and sales tools, and CRM (Customer Relation Management). The company also provides budget in supporting marketing process such as market surveys, impact studies and corporate branding by cooperating with third parties. 
- Exciter Drivers:

These drivers aim to motivate and encourage salespeople to work hard and achieve company goals. To encourage and motivate the sales force, the company does several ways such as providing compensation and incentives when sales targets are achieved, as well as providing motivational programs to salespeople.

- Controller Drivers:

PT Redceri Indonesia needs a control system to support its marketing process. The control system is used to ensure that salespeople, most of who work unattended, continue to do what they should do from time to time. These drivers direct the activity and behavior of sales force, to determine sales performance by setting targets, forecasting, reporting mechanisms, coordination and communication.

\section{CONCLUSION}

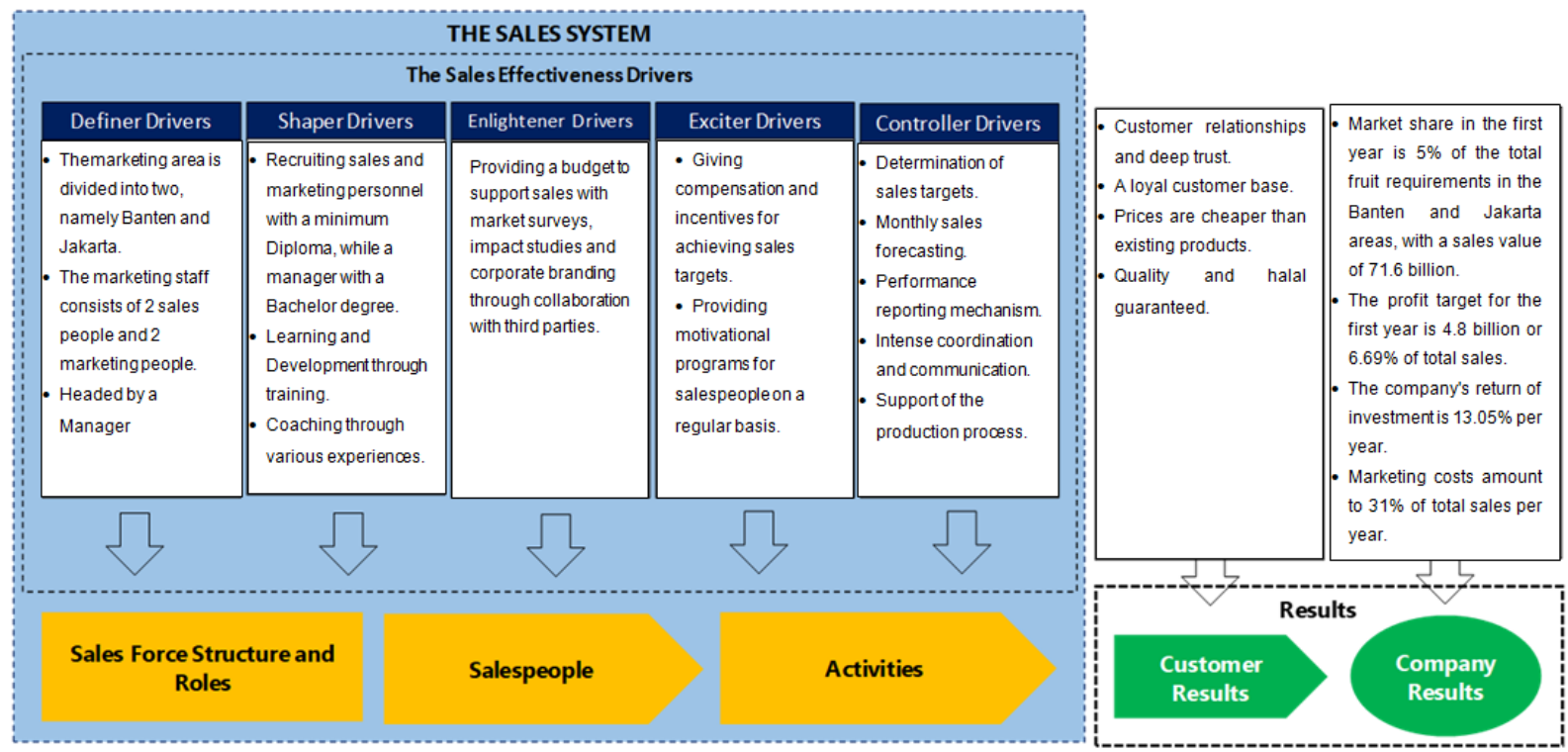

Figure 7 - Sales System PT Redceri Indonesia

The overall picture of the activity of marketing strategy implementation of PT Redceri Indonesia is depicted in Figure 7 of company's sales system.

\section{REFERENCES}

1. Graham Friend and Stefan Zehle, Guide to Business Planning, the Economist Newspaper.

2. Sidik, Ignas G. (2013). Bisnis Sukses. Jakarta: Gramedia Pustaka Utama.

3. Porter, Micheal E. (1980). Competitive Strategy. New York: Free Press.

4. Porter, Micheal E. (1985). Competitive Advantage. New York: Free Press.

5. Osterwalder, Alexander \& Pigneur, Yves. (2010). Business Model Generation. New Jersey: John Wiley \& Sons Inc.

6. Lovelock, Christopher \& Wirtz, Jochen. (2007). Services Marketing: people, technology, strategy. Australia: Pearson Prentice Hall.

7. Dwyer, Robert F. \& Tanner, John. (2005). Business Marketing: Connecting Strategy, Relationships, and Learning. New York: McGraw-Hill.

8. Mulyadi, Sistem Perencanaan dan Pengendalian Manajemen, Edisi Ketiga, Salemba Empat, Jakarta, 2007.

9. http://dewina-journal.foutap.com/tren-iklan-di-indonesia-5-tahun-ke-Depan/

10. Tanjung, Farid Aulia, 2014, "Menyusun Business Plan: Langkah Penyusunan Business Plan": http://www.bglconline.com. 